\title{
Refleksi terhadap kewarganegaraan ekologis dan tanggung jawab warga negara melalui program ecovillage
}

\author{
Lili Halimah $^{a, 1}$, Siti Fauziah Nurul ${ }^{\text {b, } 2}$ \\ a Pendidikan Pancasila dan Kewarganegaraan STKIP Pasundan, Cimahi, Indonesia \\ b Pendidikan Pancasila dan Kewarganegaraan STKIP Pasundan, Cimahi, Indonesia
}

\section{ABSTRAK}

Penelitian ini mengangkat permasalahan Sungai Citarum yang keadaannya sangat memprihatinkan walaupun pemerintah daerah telah berupaya menanganinya dengan berbagai program dan dengan biaya yang sangat besar. Kewarganegaraan ekologis merupakan gerakan sebagai upaya mengubah perilaku masyarakat agar sadar lingkungan. Civic responsibility adalah kesadaran akan hak dan kewajiban sebagai warga negara yang bertanggung jawab. Tujuan penelitian adalah menganalisis program agar dapat mengubah mindset masyarakat mempunyai kesadaran untuk mencintai lingkungan. Metode penelitian menggunakan pendekatan kualitatif dengan observasi, dan wawancara. Hasil penelitian masyarakat masih belum memiliki kesadaran untuk membantu program pemerintah daerah, hal ini disebabkan karena faktor pendidikan, status sosial dan ekonomi. Cara yang tepat untuk mempromosikan ecological citizenship dan civic responsibility adalah edukasi tingkat sekolah menengah untuk menghindari krisis lingkungan, ekonomi, dan budaya di masa depan dengan menambahkan Kurikulum Kewarganegaraan. Komunikasi aktif dari pemerintah daerah kepada masyarakat terbangun kesadaran untuk ikut membangun lingkungan.
Sejarah Artikel

Diterima : 30 November 2019

Disetujui : 30 April 2020

\section{Kata kunci:}

program ecovillage, tanggung jawab warga negara, kewarganegaraan ekologi, Citarum

\section{Keywords:}

Ecovillage, civic responsibility, ecological citizenship, Citarum

\begin{abstract}
This research about the Citarum River problem is in deplorable condition even though the local government has tried to solve it with various programs and at a very high cost. Ecological citizenship is a movement to change people's behavior so that they are environmentally aware. Civic responsibility is an awareness of the rights and obligations of the citizen. The research objective is to analyze the program to change the mindset of having the awareness to love the environment. The research method used a qualitative approach with observation and interviews. The results of the community research still do not have the awareness to help local government programs. It is due to factors of education, social, and economic status. An appropriate way to promote ecological citizenship and civic responsibility is secondary school level education to avoid future environmental, economic, and cultural crises by adding a citizenship curriculum in school. Citizen awareness can build from a good partnership between government and society.
\end{abstract}

\section{Pendahuluan}

Permasalahan lingkungan menjadi sorotan dunia. Globalisasi secara terang-terangan mengubah pemahaman kita tentang politik lingkungan (Sáiz, 2005) Lingkungan yang sehat dan bersih merupakan dua hal yang sangat penting dalam kehidupan. Perilaku Hidup bersih dan sehat merupakan langkah yang harus dilakukan untuk mencapai derajat kesehatan yang optimal bagi setiap orang. Kondisi sehat tidak serta merta terjadi, tetapi harus senantiasa diupayakan dari yang tidak sehat menjadi hidup yang sehat serta menciptakan lingkungan yang sehat (Andriansyah \& Rahmantari, 2013). Diperlukan adanya konsensus global untuk mengatasi permasalahan lingkungan 
global, yakni pembentukan masyarakat bumi yang sadar lingkungan atau ecological society (Surakusumah, 2012).

Kesehatan penduduk merupakan salah satu indikator tingkat kesejahteraan masyarakat yang antara lain dipengaruhi oleh faktor lingkungan hidup (Pudjiastuti, 2002). Pengetahuan tentang kebersihan, nilai, sikap, dan perilaku hidup bersih dari seseorang adalah hasil dari pendidikan, baik yang diterima dari keluarga, lingkungan sekolah, atau dari lingkungan masyarakat itu merupakan hal yang penting (Purbantara et al., 2013).

Sekarang ini lingkungan yang sehat dan bersih, sangat jarang terlihat. Problem lingkungan hidup dewasa ini menghadapi masalah yang cukup kompleks dan dilematis. Kerusakan lingkungan akan mengancam tidak saja terhadap keberlanjutan pembangunan itu sendiri tetapi juga akan mengancam eksistensi manusia (Sriyanto, 2007). Pencemaran lingkungan menjadi permasalahan dalam kehidupan dan telah menjadi salah satu isu penting dalam dunia internasional. Pencemaran air salah satu masalah yang banyak dihadapi oleh beberapa negara di dunia. Salah satu dampak terjadinya polusi air adalah kemajuan teknologi, ekonomi atau pun pembangunan yang mengandung risiko pencemaran dan perusakan lingkungan hidup sehingga struktur dan fungsi dasar ekosistem yang menjadi pendukung kehidupan menjadi rusak (Sya'ar, 2017).

Daerah Aliran Sungai (DAS) Citarum jika dimanfaatkan dan dikelola dengan baik akan membawa dampak positif bagi kebutuhan masyarakat sekitar. Namun saat ini Sungai Citarum dalam keadaan lumpuh dan tidak dapat digunakan oleh masyarakat sekitar karena air kotor dan jika dikonsumsi untuk keperluan sehari-hari akan berbahaya. Hasil pengukuran parameter hidrologi dan kandungan logam berat pada sampel air Sungai Citarum dan air sumur warga sekitarnya menunjukkan bahwa nilai pH, suhu, dan TDS masih di bawah ambang batas tercemar, sedangkan nilai EC menunjukkan bahwa air sumur dan air sungai telah tercemar. Hal ini dibuktikan dengan analisis kandungan logam berat yang dapat dilihat bahwa terdapat kandungan logam besi ( $\mathrm{Fe}$ ) yang cukup tinggi di atas ambang batas air bersih sehingga air tersebut tidak dapat di konsumsi bagi warga, baik untuk air sungai maupun air sumur (Krisnani et al., 2017).

Pemerintah Provinsi Jawa Barat melalui Badan Pengelola Lingkungan Hidup Daerah (BPLHD) yakni Dinas Lingkungan Hidup (DLH) Kabupaten Bandung Barat (KBB) sudah membuat program untuk mengatasi pencemaran Sungai Citarum. Salah satunya desa berbudaya lingkungan atau ecovillage yang merupakan pelibatan komunitas masyarakat di perkotaan maupun pedesaan dalam pengembangan wilayah sekitar tanpa mengeksploitasi dan membuat kerusakan. Dengan memosisikan masyarakat sebagai subjek pembangunan berkelanjutan, serta secara partisipatif mengajak masyarakat sama-sama menganalisis permasalahan lingkungan yang terjadi di sekitar masyarakat (Wafiroh, 2018).

Ecological citizenship merupakan gerakan untuk memperkenalkan masyarakat mempromosikan permasalahan lingkungan (Hayward, 2006; Melo-Escrihuela, 2008; Seyfang, 2006). Tujuan adalah mengubah mindset masyarakat terhadap pemulihan Sungai Citarum dan menjadi wadah bagi masyarakat untuk berpartisipasi aktif dalam pencapaian tujuan program. Perubahan perilaku individu, lembaga dan organisasi adalah prasyarat untuk pembangunan berkelanjutan (Dobson, 2007). Selain masyarakat, peran serta pelaku usaha, tokoh agama, akademisi, lembaga swadaya masyarakat, dan aparat pemerintah dalam membangun desa yang berwawasan lingkungan merupakan kunci pengendalian kerusakan lingkungan. Civic responsibility merupakan tindakan dan sikap yang terkait tanggung jawab sipil sebagai wujud partisipasi secara sukarela. Civic responsibility diartikan sebagai partisipasi aktif dalam kehidupan publik komunitas secara informatif, berkomitmen, dan konstruktif, dengan fokus pada kebaikan bersama (Gottlieb \& Robinson, 2006).Pengembangan 
civic responsibility dipandang sebagai komponen penting dalam keberhasilan yang menghasilkan kinerja lebih tinggi (Wilcox, 2011). Ketika lingkungan di sekitar kita tercemar maka sebagai warga negara yang baik kita harus turut berpartisipasi aktif dalam membantu program pemerintah setempat. Partisipasi warga negara dalam menjaga kelestarian lingkungan hidup menjadi elemen yang penting karena warga negara menjadi bagian dari lingkungan hidup sendiri (Aulia et al., 2018).

Ecovillage atau desa budaya yang dibentuk oleh pemerintah pada prinsipnya harmoni dengan konsep ecological citizenship dan civic responsibility karena mempunyai peran yang sama mengajak masyarakat agar mencintai lingkungan sekitar. Maka dari itu, peneliti tertarik untuk menganalisis benang merah program ecovillage, ecological citizenship, dan civic responsibility dalam mengatasi permasalahan Sungai Citarum. Tujuan penelitian ini adalah mencari solusi yang tepat dapat melibatkan masyarakat dan stakeholder secara sadar sehingga mencintai lingkungan sekitarnya.

\section{Metode}

Pendekatan dalam penelitian ini adalah dengan pendekatan kualitatif berfokus kepada prosesproses yang terjadi, atau hasil (Creswell, 2010). Peneliti melakukan observasi dibantu oleh pemandu ecovillage dan masyarakat sekitarnya. Pada saat wawancara, kami menemui orang-orang yang berperan langsung dalam mengatasi permasalahan Sungai Citarum, sehingga memperoleh data secara sistematis, faktual dan akurat.

\section{Hasil dan Pembahasan}

DLH KBB terletak di Desa Mekarsari Kelurahan Padalarang Kecamatan Ngamprah. KBB memiliki sungai utama yakni Sungai Citarum, yang melintasi dan memiliki peran penting bagi kehidupan masyarakat. KBB salah satu wilayah yang tidak lepas dari permasalahan lingkungan. Berdasar pada kondisi di atas, maka perlu strategi untuk mengatasi munculnya persoalan-persoalan yang tertuang dalam Rencana Pembangunan Jangka Menengah Daerah (RPJMD), kebutuhan nyata untuk mengantisipasi berbagai persoalan aktual yang akan dihadapi oleh seluruh masyarakat yakni diantaranya adalah kurangnya kesadaran masyarakat terhadap lingkungan dan pemberdayaan masyarakat untuk peduli terhadap pengelolaan sampah secara mandiri (Lampiran RJPMD Kabupaten Bandung Barat Tahun 2013-2018).

DAS Citarum mempunyai fungsi penting bagi masyarakat Jawa Barat maupun Jakarta. Luas DAS Citarum Hulu sekitar 2.340,88 km2 dengan jumlah penduduk 5,7 juta jiwa di tahun 2001. Di Kawasan DAS Citarum Hulu mengalir sungai utama, yaitu Citarum. Air sungai ini digunakan sebagai sumber air minum, pertanian, perikanan, serta merupakan sumber air bagi tiga waduk (volume total 6.147 juta m3) untuk keperluan irigasi seluas 300.000 ha dan pembangkit tenaga listrik Pulau Jawa dan Bali dengan daya total 5.000 giga watt hours (Wangsaatmaja et al., 2006).

DAS Citarum jika dimanfaatkan dan dikelola dengan baik akan membawa dampak yang sangat baik bagi kebutuhan masyarakat sekitar. Hal ini dibuktikan bahwa menurut sensus Badan Pusat Statistik (BPS) tahun 2012 menyatakan dari 45 juta penduduk Jawa Barat sebanyak 15 juta warga menggantungkan hidupnya dari Sungai Citarum. Namun sangat disayangkan, penduduk KBB sekitar 1,4 juta orang kurang peka akan kesadaran sebagai warga negara dan mengakibatkan lingkungan kotor dan tidak sehat menjadi suatu kebiasaan di kalangan masyarakat. Diperlukan partisipasi aktif, berkomitmen, dan konstruktif, dengan fokus pada kebaikan bersama mengelola lingkungan Hal ini menunjukkan bahwa setiap warga negara harus memiliki kesadaran dan rasa tanggung jawab dalam menjaga lingkungan (Gottlieb \& Robinson, 2006). 
Kerusakan lingkungan akan mengancam tidak saja terhadap keberlanjutan pembangunan itu sendiri tetapi juga akan mengancam eksistensi manusia. Perencanaan dan pelaksanaan kebijaksanaan dan program-program pengelolaan lingkungan hidup harus melibatkan masyarakat dalam pengambilan keputusan. Selain itu, juga harus memberikan manfaat yang besar dalam peningkatan kesejahteraan masyarakat. Dan yang lebih penting adalah harus dapat mewujudkan pembangunan yang berwawasan lingkungan dan berkelanjutan (Sriyanto, 2007).

Permasalahan yang terjadi di wilayah Sungai Citarum didominasi oleh rendahnya kepedulian masyarakat dan pemerintah sekitar terhadap kelestarian alam. Perencanaan skenario berbasis tempat dapat secara sistematis mengeksplorasi dan mengantisipasi ketidakpastian masa depan mengenai interaksi antara manusia dan lingkungan. (Achieng, Richard, Robert, Jessica, \& Nicholas, 2019). Fasilitas yang disediakan DLH, pengadaan sarana prasarana kebersihan lingkungan seperti penyediaan truk sampah, tong sampah, motor pengangkut sampah dan peralatan lainnya seharusnya dimanfaatkan dengan baik. Tugas utama DLH adalah mengajak atau mengikutsertakan secara langsung masyarakat dalam menjaga kelestarian lingkungan agar tidak menimbulkan kerugian yang besar terhadap kesehatan, ekonomi, sosial, ekosistem, dan sumber daya lingkungan.

Target program DLH adalah mengubah pola pikir masyarakat terhadap kebersihan, keindahan dan kelestarian Sungai Citarum. Proses yang dilakukan untuk membangun kesadaran masyarakat sekitar dengan cara melibatkan stakeholder yakni kades, fasilitator dan kader ecovillage. Namun beberapa kegiatan dalam program tersebut masih belum menyentuh semua lapisan masyarakat. Berdasarkan hasil wawancara dengan tokoh masyarakat AS, EK, dan AK dalam proses implementasi program-program yang diadakan oleh pemerintah telah berjalan sudah cukup baik, dan mampu menarik perhatian masyarakat untuk hadir namun sebagian dari mereka tidak mengetahui bagaimana program-program tersebut sebenarnya meskipun mereka hanya membaca kegiatan melalui baliho atau spanduk.

Berdasarkan pemaparan $\mathrm{N}$, berkenaan dengan pengawasan dan keberlanjutan dari pelaksanaan program-program DLH, diperlukan kontrol dari Kades dan kader ecovillage yang menyebarkan budaya cinta lingkungan di masyarakat. Sedangkan keberlanjutan dari pihak desa dan fasilitator DLH selalu melakukan kegiatan peduli lingkungan dan kader ecovillage berupa sosialisasi atau event. Program ecovillage belum dapat dikatakan berhasil dalam mengubah perilaku masyarakat seutuhnya, karena pasca pelaksanaan program DLH, masyarakat seharusnya terbangun secara sadar dan lebih peduli terhadap lingkungan sekitarnya.

Oleh karena itu, BPLHD melalui DLH KBB sudah membuat program dengan biaya yang tinggi untuk mengatasi pencemaran Sungai Citarum dengan tujuan mewujudkan menjadi sungai bersih dan ada perubahan dari perilaku masyarakat di sekitar KBB. Program-program tersebut dapat di lihat pada tabel berikut.

Tabel 1. Program Pengelolaan Sungai Citarum

\begin{tabular}{|c|c|c|}
\hline Tahun & Program & Isi \\
\hline $\begin{array}{l}\text { Dicanangkan } \\
\text { pada periode } \\
\text { tahun } 2000 \text { sd } \\
2003\end{array}$ & $\begin{array}{l}\text { Program Citarum } \\
\text { Bergetar (bersih, } \\
\text { geulis/cantik, dan } \\
\text { lestari) }\end{array}$ & $\begin{array}{l}\text { Program ini fokus pada pengendalian pemulihan konversi dan } \\
\text { pemberdayaan masyarakat. Namun selanjutnta, program ini } \\
\text { dianggap belum optimal mengatasi pencemaran di sungai yang } \\
\text { menghidupi setidaknya } 27.5 \text { juta jiwa warga Jawa Barat dan DKI } \\
\text { Jakarta. }\end{array}$ \\
\hline $\begin{array}{l}\text { Tahun } 2008 \text { sd } \\
\text { tahun } 2023\end{array}$ & $\begin{array}{l}\text { Program } \\
\text { Integrated } \\
\text { Citarum Water } \\
\text { Resources } \\
\text { Management }\end{array}$ & $\begin{array}{l}\text { Program pengelolaan sumber daya air terpadu di wilayah Sungai } \\
\text { Citarum yakni program jangka panjang tahun } 2008 \text { sd tahun } 2023 \\
\text { atau. Melihat sejuta perkara di salah satu sungai strategis nasional } \\
\text { ini, pemerintah pusat tentu tidak bias tinggal diam pada tahun } \\
\text { 2008, pemerintah menyepakati tawaran pinjaman dari Asian }\end{array}$ \\
\hline
\end{tabular}




\begin{tabular}{|c|c|c|}
\hline Tahun & Program & Isi \\
\hline & $\begin{array}{l}\text { Investment } \\
\text { program } \\
\text { (ICWRMIP) }\end{array}$ & $\begin{array}{l}\text { Development Bank (ABD) untuk memulihkan Citarum. Besar paket } \\
\text { pinjaman senilai USD } 500 \text { juta atau sekitar Rp. 6,7 triliun untuk } \\
\text { program selama } 15 \text { tahun. Program ini melibatkan Akademisi, LSM, } \\
\text { hingga kalangan usaha ini bertujuan untuk perbaikan daerah } \\
\text { tangkapan air di hulu hingga peningkatan kualitas dan ketersediaan } \\
\text { air minum. Baru berjalan } 3 \text { tahun, program ini diprotes oleh } \\
\text { kalangan Akademis bersama Koalisi Rakyat untuk hak atas air } \\
\text { (Kruha). Program justru dianggap merugikan warga, tidak jelas, } \\
\text { bahkan tidak sesuai dengan tujuan awal pelaksanaan proyek, serta } \\
\text { minus transparansi anggaran. }\end{array}$ \\
\hline $\begin{array}{l}\text { Program } \\
\text { pemulihan pada } \\
\text { tahun } 2013 \text {, }\end{array}$ & $\begin{array}{l}\text { Program Citarum } \\
\text { Bestari }\end{array}$ & $\begin{array}{l}\text { Program ini bermakna "baik budi pekerti" merupakan kependekan } \\
\text { dari bersih, sehat, indah dan lestari. Pada tahun } 2018 \text { air sungai } \\
\text { Citarum dapat langsung diminum. Melalui peraturan Gubernur } \\
\text { Jabar Nomor } 75 \text { Tahun 2015, gerakan Citarum Bestari resmi } \\
\text { diluncurkan. Anggaran sekitar Rp. } 80 \text { miliar pun disiapkan demi } \\
\text { memuluskan jalan menggapai target Citarum Bestari. }\end{array}$ \\
\hline 14 Maret 2018 & $\begin{array}{l}\text { Program Citarum } \\
\text { Harum }\end{array}$ & $\begin{array}{l}\text { Program ini lahir dari Perpres Nomor } 15 \text { tahun } 2018 \text { tentang } \\
\text { percepatan pengendalian pencemaran kerusakan Daerah Aliran } \\
\text { Sungai Citarum yang ditandatangani Presiden Jokowi. Presiden } \\
\text { Jokowi resmi membentuk tim pengendalian pencemaran dan } \\
\text { kerusakan aliran Sungai Citarum, yang disebut Tim Das Citarum. } \\
\text { Periode } 6 \text { bulan pertama Citarum Harum ditujukan untuk sosialisasi } \\
\text { sekaligus penegakan hukum terhadap industri penghasil limbah } \\
\text { yang bandel. Rencananya, program ini akan merelokasi warga desa } \\
\text { Tarumajaya yang tinggal di bantaran Hulu Sungai Citarum. } \\
\text { Banyaknya pendapat yang tentunya berbeda-beda mengurangi } \\
\text { berjalannya program yang optimal. }\end{array}$ \\
\hline Tahun 2020 & $\begin{array}{l}\text { Program Citarum } \\
\text { harum focus ke } \\
\text { penghijauan } \\
\text { Kawasan }\end{array}$ & $\begin{array}{l}\text { Citarum Harus sudah mulai memperlihatkan hasil positif. Satu per } \\
\text { satu persoalan di sepanjang Daerah Aliran Sungai (DAS) Citarum } \\
\text { berangsur membaik. Deputi IV Bidang Koordinasi SDM, IPTEK, dan } \\
\text { Budaya Maritim Kemenko Bidang Kemaritiman dan Investasi Safri } \\
\text { Burhanuddin meninjau sejumlah titik DAS Citarum, Yakni, mulai dari } \\
\text { hulu sungai Citarum sampai command center Citarum Harum. }\end{array}$ \\
\hline
\end{tabular}

Sumber: Data Hasil Penelitian, 2019.

Ecovillage merupakan desa/kampung berbudaya lingkungan di mana masyarakatnya mampu mengelola lingkungan sesuai dengan kaidah keberlanjutan yakni meliputi konservasi, pemanfaatan dan pemulihan lingkungan. Pengembangan ecovillage diterapkan di level desa dengan pertimbangan desa merupakan wilayah otonomi yang memiliki peran strategis dalam memelihara sumber daya alam, lingkungan, peninggalan bersejarah, pengembangan ekonomi masyarakat, dan sosial budaya (Sunaedi \& As'ari, 2018). Keberadaan program ecovillage yang dikeluarkan pemerintah amat bergantung pada keterlibatan warga negara yang sadar akan lingkungan serta bertanggungjawab akan lingkungan hidupnya (Karatekin \& Uysal, 2018; Latta \& Garside, 2005). Program ini sia-sia jika tak didukung rasa peduli warga akan kelestarian lingkungan sekitarnya. Karena itu, tumbuhnya kesadaran warga menjadi ujung tombak keberhasilan dan keberlanjutan pengembangan ecovillage di semua desa. Maka perlu perubahan perilaku individu, lembaga dan organisasi adalah prasyarat untuk pembangunan berkelanjutan dari program ecovillage (Dobson, 2007) Peran serta masyarakat, pelaku usaha, tokoh agama, akademisi, lembaga swadaya masyarakat, dan aparat pemerintah dalam 
membangun desa yang berwawasan lingkungan merupakan kunci pengendalian kerusakan lingkungan. utama dalam korporasi tipikal adalah investor, karyawan, pelanggan, dan pemasoknya.

Dalam program pengelolaan sumber daya alam dan lingkungan, terutama di perdesaan pengetahuan dan kearifan lokal mengenai upaya konservasi dan peraturan yang mengatur perilaku anggota masyarakat dalam pemeliharaan lingkungan hidup sangat menentukan tercapainya ecovillage (Sunaedi \& As'ari, 2018). Tanggung jawab merupakan hal terpenting yang harus dimiliki tiap-tiap orang. Masyarakat belum sepenuhnya menyadari potensi besar Sungai Citarum jika dibiarkan tercemar dan rusak tanpa ditindaklanjuti. Limbah hara dari input perkotaan dan pertanian telah menghasilkan konsentrasi nitrat yang tinggi dalam ekosistem air tawar. Paparan nitrat dapat sangat mengancam organisme air. Secara keseluruhan, dampak nitrat dan stressor tambahan rumit yang membutuhkan pendekatan holistik untuk lebih melindungi keanekaragaman hayati air tawar dalam menghadapi perubahan global yang sedang berlangsung (Isaza et al., 2020).

Berdasarkan desain program, ecovillage dimaksudkan untuk membentuk kesadaran kritis warga terhadap kondisi ekologi sekitarnya. Karena itu, keberadaan fasilitator dan kader ecovillage sebagai unsur pembentuk karakter dan kesadaran warga. Ecovillage adalah desa/kampung berbudaya lingkungan dimana masyarakatnya mampu mengelola lingkungannya sesuai dengan kaidah keberlanjutan meliputi konservasi, pemanfaatan dan pemulihan lingkungan. Selanjutnya ecovillage sebagai bentuk interaksi manusia terhadap lingkungan untuk mencapai kehidupan berkelanjutan dan lestari. Hasil penelitian Wafiroh (2018), program ecovillage di Desa Langensari Kabupaten Bandung melalui pendekatan fleksibel yakni memosisikan masyarakat sebagai subjek pembangunan berkelanjutan, serta secara partisipatif mengajak masyarakat untuk sama-sama menganalisis permasalahan lingkungan yang terjadi di sekitar masyarakat. Pengembangan masyarakat melalui program ecovillage dalam pelestarian hidup sudah tepat dan menjadikan masyarakat swadaya dan peduli terhadap kelestarian lingkungan hidup.

Masalah pencemaran lingkungan akibat minimnya pengelolaan sampah merupakan masalah yang pada beberapa wilayah belum teratasi dan menjadi beban serta permasalahan serius hampir di seluruh kabupaten/kota. Masalah tersebut muncul disebabkan karena sampah (khususnya sampah yang bersumber dari rumah tangga) tidak tertangani dengan baik. Rendahnya kesadaran masyarakat, keterbatasan lahan TPA, serta keterbatasan kemampuan pemerintah daerah dalam hal pembiayaan menjadi faktor pendukung yang mengakibatkan semakin kompleksnya masalah sampah tersebut. Kendala keterbatasan pendanaan dari pemerintah mengakibatkan harus dilakukannya upaya pencarian alternatif penanganan persampahan dengan tidak mengandalkan pendanaan dari Pemerintah. Melihat kondisi tersebut, penanganan sampah rumah tangga tidak dapat menjadi hanya tanggungjawab pemerintah saja, namun idealnya masalah penanganan sampah juga menjadi tanggungjawab masyarakat itu sendiri sebagai penghasil sampah. Karena pada dasarnya masyarakat mempunyai potensi besar untuk memberikan kontribusi dalam hal pengolahan sampah (Krisnani et al., 2017)

Diperlukan adanya konsensus global untuk mengatasi permasalahan lingkungan global, yakni pembentukan masyarakat bumi yang sadar lingkungan (Surakusumah, 2012). Berdasar pada pendapat tersebut DLH KBB bertujuan menjadi wadah bagi masyarakat untuk berpartisipasi aktif dalam pencapaian tujuan. Masyarakat harus dapat berperan dan memiliki sikap tanggung jawab terhadap lingkungan sebab manusia merupakan makhluk yang dibekali oleh pengetahuan, tujuan, kepercayaan dan nilai-nilai. Perlu ada transformasi pengalaman dari masyarakat yang mengikuti kegiatan terhadap masyarakat yang tidak mengikuti kegiatan secara langsung. Hal ini sangat 
berpengaruh tentunya terhadap hasil yang diharapkan mengenai penanaman tanggung jawab warga negara khususnya masyarakat KBB terhadap lingkungan Sungai Citarum.

Ecovillage mengandung pengertian sebagai suatu ekosistem dimana masyarakat pedesaan atau perkotaan yang ada di dalamnya berusaha mengintegrasikan kelestarian lingkungan sosial dengan cara hidup berdampak rendah untuk mencapai hal ini, mereka mengintegrasikan berbagai aspek desain ekologis, agrikultur permanen, bangunan ekologis, produksi hijau, energi alternatif, bangunan masyarakat, dan banyak lagi. Ecovillage sebagai bentuk interaksi manusia terhadap lingkungan untuk mencapai kehidupan berkelanjutan dan lestari (Sunaedi \& As'ari, 2018). Kegiatan ecovillage atau pengembangan desa berbudaya lingkungan, bertujuan untuk mengubah pola pikir dan perilaku masyarakat agar lebih peduli terhadap lingkungan. Kegiatan ecovillage disosialisasikan kepada masyarakat, pelaku usaha, tokoh agama, LSM, aparat pemerintah, dll sebagai salah usaha dari proses implementasi program yang ada di DLH KBB. Kegiatan ini menaruh harapan besar agar masyarakat dapat berpartisipasi aktif dan mandiri untuk bersama-sama menjadikan Sungai Citarum lebih baik dan lestari. Masyarakat pada umumnya diberikan pelatihan dan bimbingan teknis (bimtek) dalam pelaksanaan ecovillage di lingkungan masyarakatnya. Hal tersebut dimaksudkan untuk disebarluaskan kembali kepada masyarakat yang lain agar mampu memahami tujuan dari program tersebut serta terbangunnya pola pikir peduli akan lingkungan.

Warga negara harus bisa bekerjasama dan bertanggung jawab terhadap peran dan kewajibannya di masyarakat. Artinya, tindak lanjut dari kegiatan ecovillage adalah bagaimana masyarakat yang sudah mendapatkan pelatihan dan bimtek dapat mempertanggung jawabkan pengetahuannya untuk disebarluaskan pada masyarakat lain.

Festival program-program merupakan salah satu wadah aplikatif bagi masyarakat. Tujuan dari pelaksanaan kegiatan tersebut untuk memperkuat dan mendorong komitmen masyarakat. Berikut kegiatan festival program-program yang sudah dilaksanakan, dirangkum dalam tabel berikut

Tabel 2. Festival Program-Program DLH KBB

\begin{tabular}{|c|c|c|c|}
\hline No & Kegiatan & Deskripsi Kegiatan & Tujuan \\
\hline 1. & $\begin{array}{l}\text { Pagelaran } \\
\text { Sendratari } \\
\text { Handaru Citarum }\end{array}$ & $\begin{array}{l}\text { Menceritakan tentang kondisi } \\
\text { Sungai Citarum yang sakit dapat } \\
\text { pulih kembali akibat dari } \\
\text { kerjasama masyarakat untuk } \\
\text { menjadikannya lestari. }\end{array}$ & $\begin{array}{l}\text { Memperkuat dan mendorong komitmen } \\
\text { masyarakat. Idealnya setelah kegiatan } \\
\text { selesai, masyarakat mampu mengambil } \\
\text { manfaat dan mentransformasikan hal } \\
\text { tersebut kepada lingkungannya }\end{array}$ \\
\hline 2. & $\begin{array}{l}\text { Forum Groups } \\
\text { Discussion (FGD) }\end{array}$ & $\begin{array}{l}\text { Masyarakat secara umum, para } \\
\text { ulama, aparatur pemerintahan, } \\
\text { pelaku usaha dan LSM } \\
\text { Mengubah mindset dan perilaku } \\
\text { masyarakat agar peduli terhadap } \\
\text { lingkungan }\end{array}$ & $\begin{array}{l}\text { Rencana strategis dalam proses } \\
\text { implementasi Program-program DLH untuk } \\
\text { melibatkan unsur-unsur dari masyarakat } \\
\text { yang memiliki pengaruh besar untuk } \\
\text { ketercapaian tujuan dari program-program } \\
\text { yang ada. }\end{array}$ \\
\hline 3. & $\begin{array}{l}\text { Persembahan } \\
\text { Wayang Golek }\end{array}$ & $\begin{array}{l}\text { Pertunjukan wayang dirasa tepat } \\
\text { untuk dilaksanakan karena } \\
\text { sesuai dengan kultur dan kondisi } \\
\text { sosial ekonomi masyarakat KBB. } \\
\text { Selain mengandung unsur } \\
\text { hiburan, terdapat kandungan } \\
\text { pesan dan nilai-nilai dalam } \\
\text { menjaga lingkungan. }\end{array}$ & $\begin{array}{l}\text { Memupuk kembali kesadaran dan } \\
\text { kepedulian terhadap lingkungan di } \\
\text { masyarakat KBB. Tema yang diangkat pada } \\
\text { saat pertunjukan wayang adalah "Citarum } \\
\text { Harum". Pertunjukan wayang golek } \\
\text { dimaksudkan untuk menarik partisipasi } \\
\text { masyarakat agar dapat mengikuti kegiatan } \\
\text { dalam proses implementasi program- } \\
\text { program DLH }\end{array}$ \\
\hline 4. & $\begin{array}{l}\text { Lomba } \\
\text { lomba }\end{array}$ & $\begin{array}{l}\text { Semua jenis perlombaan } \\
\text { tersebut mengangkat satu tema }\end{array}$ & $\begin{array}{l}\text { Menyosialisasikan dan mendukung tujuan } \\
\text { program untuk menjadikan sungai Citarum }\end{array}$ \\
\hline
\end{tabular}




\begin{tabular}{|c|c|c|c|}
\hline No & Kegiatan & Deskripsi Kegiatan & Tujuan \\
\hline & $\begin{array}{l}\text { lomba membuat } \\
\text { lagu, lomba puisi, } \\
\text { lomba } \\
\text { mewarnai, } \\
\text { lomba fotografi, } \\
\text { Citarum }\end{array}$ & $\begin{array}{l}\text { yakni "Citarum Harum". } \\
\text { Kegiatan Lomba Fokus Citarum } \\
\text { dijadikan sebagai wadah antara } \\
\text { pemerintah dan masyarakat }\end{array}$ & $\begin{array}{l}\text { yang artinya jihad lingkungan bersama- } \\
\text { sama. Pasal (67) dalam Undang-Undang } \\
\text { Nomor } 32 \text { Tahun } 2009 \text { tentang } \\
\text { Perlindungan dan Pengelolaan Lingkungan } \\
\text { Hidup akan membantu dalam pembahasan } \\
\text { ini. Dalam pasal tersebut dijelaskan bahwa } \\
\text { setiap orang berkewajiban memelihara } \\
\text { kelestarian lingkungan hidup serta } \\
\text { mengendalikan pencemaran dan/atau } \\
\text { kerusakan lingkungan hidup }\end{array}$ \\
\hline
\end{tabular}

Sumber: Data hasil penelitian, 2019

Namun kegiatan festival tersebut belum dapat membangun civic responsibility. Hal ini sebagai akibat dari rendahnya pendidikan masyarakat KBB pada umumnya. Dari hasil pengamatan, respon baik terhadap kegiatan sudah terlihat. Akan tetapi banyaknya partisipasi masyarakat dalam kegiatan festival program yang tengah berjalan belum mampu mengubah pola pikir dan perilaku masyarakat untuk peduli terhadap lingkungan. Perubahan pola pikir masih belum tercapai, dikarenakan orientasi dari sebagian masyarakat menghadiri festival program DLH untuk menikmati fasilitas kegiatan setelah kegiatan selesai masyarakat kembali ketempat tinggalnya tanpa berbuat apa-apa seakan kegiatan tersebut hanya sebatas seremonial saja.

Peran serta masyarakat, pelaku usaha, tokoh agama, akademisi, lembaga swadaya masyarakat, dan aparat pemerintah dalam membangun desa yang berwawasan lingkungan merupakan kunci pengendalian kerusakan lingkungan. Dalam program pengelolaan sumber daya alam dan lingkungan, terutama di pedesaan pengetahuan dan kearifan lokal mengenai upaya konservasi dan peraturan yang mengatur perilaku anggota masyarakat dalam pemeliharaan lingkungan hidup sangat menentukan tercapainya ecovillage (Sunaedi \& As'ari, 2018). Masyarakat masih kurang terlibat dalam menyelesaikan masalah lingkungan yang ada di wilayahnya. Warga negara yang baik adalah warga negara yang mengetahui kewajibannya, memiliki sifat keutamaan dan kebajikan. Maka dari itulah, seyogiyanya masyarakat menunjukkan partisipasinya dalam program yang dicanangkan pemerintah sebagai wujud kesadaran dan tanggung jawabnya terhadap lingkungan. Idealnya masyarakat ketika dihadapkan dengan suatu permasalahan dia juga memiliki keinginan untuk terlibat dalam tahap pencarian solusi dan berpartisipasi aktif dalam proses penyelesaiannya. Seperti permasalahan yang dihadapi masyarakat KBB, diberikan program serta pelatihan dan bimtek oleh pemerintah akan tetapi transformasi dan aktualisasi di lingkungannya belum optimal.

Kekayaan lingkungan dapat dimanfaatkan oleh manusia untuk kelangsungan hidupnya. Berkenaan dengan hal tersebut perlu kiranya masyarakat berupaya dalam menjaga kebersihan, keindahan dan kelestarian sungai Citarum, serta berupaya dalam perubahan mindset masyarakat untuk peduli terhadap lingkungan. Tidak dapat dimungkiri bahwa segala bentuk aktivitas manusia bersinggungan langsung dengan lingkungan. Maka dalam membangun civic responsibility masyarakat salah satunya dapat dilihat dari komitmen stakeholder untuk mentransformasikan hasil FGD kepada masyarakat luas. Dalam membangun civic responsibility masyarakat, stakeholder memiliki peran penting untuk membentuk mindset dan perilaku masyarakat agar peduli terhadap lingkungan. Namun realitanya, masih ada stakeholder yang belum mampu mentransformasikan tujuan dari implementasi program-program DLH ini kepada masyarakat luas. Stakeholder yang mengikuti kegiatan FGD harus menjadi promotor dalam perubahan mindset dan perilaku masyarakat agar lebih peduli terhadap lingkungannya. Tugas dari stakeholder itu sendiri menyosialisasikan, mengawasi dan mengarahkan masyarakat agar dapat berperan aktif untuk membenahi sungai Citarum secara bersama-sama. 
Tanggung jawab merupakan tindakan pengambilan keputusan yang bersifat moral (Hermawan, 2013). Idealnya setelah mengikuti kegiatan pertunjukan wayang masyarakat mampu mengambil pesan moral dan nilai-nilai yang tersisip dalam alur cerita, lalu mentransformasikan kepada masyarakat yang tidak mengikuti kegiatan tersebut. Perilaku manusia berangkat dari tingkat kesehatan. Bahkan kesehatan masyarakat dipengaruhi oleh dua faktor yaitu faktor perilaku dan faktor di luar perilaku. Perilaku itu sendiri ditentukan dari tiga faktor berikut. Pertama, Faktor predisposisi yang terwujud dari pengetahuan, sikap, kepercayaan, keyakinan, dan nilai. Kedua, faktor pendukung yang terwujud dalam lingkup fisik, tersedianya fasilitas dan sarana kesehatan misalnya puskesmas, obat-obatan, media informasi, dan sarana pendidikan. Ketiga, Faktor penguat yang terwujud dalam sikap dan perilaku petugas kesehatan (Sunaedi \& As'ari, 2018). Mengenai kegiatan Lomba Fokus, berdasarkan Pasal (67) dalam Undang-Undang Nomor 32 Tahun 2009 tentang Perlindungan dan Pengelolaan Lingkungan Hidup dijelaskan bahwa setiap orang berkewajiban memelihara kelestarian lingkungan hidup serta mengendalikan pencemaran dan/atau kerusakan lingkungan hidup.

Kerusakan lingkungan akan mengancam tidak saja terhadap keberlanjutan pembangunan itu sendiri tetapi juga akan mengancam eksistensi manusia. Perencanaan dan pelaksanaan kebijaksanaan dan program-program pengelolaan lingkungan hidup harus melibatkan masyarakat dalam pengambilan keputusan. Selain itu, juga harus memberikan manfaat yang besar dalam peningkatan kesejahteraan masyarakat. Sebuah artikel ini meneliti representasi sosial air dalam budaya perkotaan Argentina, dimana menempatkan subjek sebagai masalah minat akademis dan praktis. Tentang kegunaan air adan tindakan warga secara fungsional, afektif, estetika secara individu maupun kolektifitas (Biagi \& Ferro, 2011), dan yang lebih penting adalah harus dapat mewujudkan pembangunan yang berwawasan lingkungan dan berkelanjutan (Sriyanto, 2007)

Permasalahan yang terjadi di wilayah sungai Citarum didominasi oleh rendahnya kepedulian masyarakat dan pemerintah sekitar terhadap kelestarian alam di wilayah sungai Citarum. Perencanaan skenario berbasis tempat dapat secara sistematis mengeksplorasi dan mengantisipasi ketidakpastian masa depan mengenai interaksi antara manusia dan lingkungan (Ouko et al., 2019). Edukasi dan komunikasi secara mutlak perlu dilakukan oleh pemerintah untuk meningkatkan partisipasi aktif masyarakat di dalam penanganan masalah lingkungan. Pemerintah dan berbagai pihak terkait harus berupaya untuk memberikan pengetahuan yang benar kepada masyarakat, terutama mengenai kelestarian lingkungan hidup (Imansyah, 2012).

\section{Simpulan}

Penyelesaian masalah Sungai Citarum menjadi tanggung jawab tidak saja pemerintah pusat atau daerah tetapi sudah merupakan tanggungjawab kita sebagai masyarakat. Kegiatan ecovillage untuk mengubah mindset dan perilaku masyarakat agar lebih peduli terhadap lingkungan dan membentuk kesadaran kritis warga terhadap kondisi ekologi sekitarnya. Ecological citizenship merupakan gerakan untuk memperkenalkan masyarakat mempromosikan permasalahan lingkungan. Tujuan adalah mengubah mindset masyarakat terhadap pemulihan Sungai Citarum, dan menjadi wadah bagi masyarakat untuk berpartisipasi aktif dalam pencapaian tujuan program. Civic responsibility memiliki peran penting untuk membentuk mindset dan perilaku masyarakat agar peduli masyarakat, dan aparat pemerintah dalam membangun desa yang berwawasan lingkungan merupakan kunci pengendalian kerusakan lingkungan.

\section{Ucapan Terima Kasih}

Kami mengucapkan terima kasih kepada STKIP Pasundan yang telah memberikan ijin penelitian, Pemerintah Daerah KBB melalui DLH yang sangat membantu peneliti memberikan data 
pada proses wawancara di tengah-tengah kesibukan mereka, Kepala Desa Margalaksana KBB yang juga turut membantu kami, dan juga kepada Bapak dan Ibu narasumber di DLH lainnya yang tidak disebutkan satu persatu.

\section{Referensi}

Andriansyah, Y., \& Rahmantari, D. N. (2013). Penyuluhan dan praktik PHBS (perilaku hidup bersih sehat) dalam mewujudkan masyarakat desa peduli sehat. Inovasi Dan Kewirausahaan, 2(1), 45-50.

Aulia, S. S., Arif, D. B., \& Arpannudin, I. (2018). PPKn dan etika lingkungan hidup di sekolah adiwiyata. Prosiding Seminar Nasional "Pengembangan Profesionalisme Dosen dan Guru Indonesia," 2, 82-88.

Biagi, M., \& Ferro, M. (2011). Ecological citizenship and social representation of water: Case study in two Argentine cities. SAGE Open, 1(2), 1-8. https://doi.org/10.1177/2158244011417897

Creswell, J. (2010). Research design: pendekatan kualitatif, kuantitatif, dan campuran. Pustaka Pelajar.

Dobson, A. (2007). Environmental citizenship: Towards sustainable development. Sustainable Development, 15(5), 276-285. https://doi.org/10.1002/sd.344

Gottlieb, K., \& Robinson, G. (Eds.). (2006). A practical guide for integrating civic responsibility into the curriculum (Second Edi). Community College Press.

Hayward, T. (2006). Ecological citizenship: Justice, rights and the virtue of resourcefulness. Environmental Politics, 15(3), 435-446. https://doi.org/10.1080/09644010600627741

Hermawan, I. C. (2013). Revitalisasi pendidikan politik dalam pendidikan kewarganegaraan di Indonesia. Jurnal Kajian Pendidikan, 3(1), 9-26. https://mindamas-journals.com/atikan/article/view/141

Imansyah, M. F. (2012). Studi umum permasalahan dan solusi DAS Citarum serta analisis kebijakan pemerintah. Jurnal Sosioteknologi, 11(25), 18-33.

Isaza, D. F. G., Cramp, R. L., \& Franklin, C. E. (2020). Living in polluted waters: A meta-analysis of the effects of nitrate and interactions with other environmental stressors on freshwater taxa. Environmental Pollution, 261, 114091. https://doi.org/10.1016/j.envpol.2020.114091

Karatekin, K., \& Uysal, C. (2018). Ecological citizenship scale development study. International Electronic Journal of Environmental Education, 8(2), 82-104.

Krisnani, H., Humaedi, S., Ferdryansyah, M., Asiah, D. H. S., Basar, G. G. K., Sulastri, S., \& Mulyana, N. (2017). Perubahan pola pikir masyarakat mengenai sampah melalui pengolahan sampah organik dan non organik di Desa Genteng, Kecamatan Sukasari, Kab. Sumedang. Jurnal Penelitian \& PPM, 4(2), 281-289. https://doi.org/10.24198/jppm.v4i2.14345

Latta, A., \& Garside, N. (2005). Perspectives on ecological citizenship: An introduction. Environments, 33(3), $1-8$.

Melo-Escrihuela, C. (2008). Promoting ecological citizenship: Rights, duties and political agency. Acme, 7(2), 113-134.

Ouko, C. A., Mulwa, R., Kibugi, R., Thorn, J. P. R., \& Oguge, N. (2019). Prospects of scenario planning for Kenya's protected ecosystems: An example of Mount Marsabit. Current Research in Environmental Sustainability, 1, 7-15. https://doi.org/10.1016/j.crsust.2019.10.001

Purbantara, A., Purwono, E. P., \& Rustiadi, T. (2013). Survei kebersihan pribadi siswa sekolah dasar negeri dalam wilayah pedesaan dan perkotaan di Kabupaten Semarang tahun ajaran 2012/2013. Journal of Physical Education, Sport, Health and Recreation, 2(6), 368-371.

http://journal.unnes.ac.id/sju/index.php/peshr

Sáiz, A. V. (2005). Globalisation, cosmopolitanism and ecological citizenship. Environmental Politics, 14(2), 
Lili Halimah, Siti Fauziah Nurul, Refleksi terhadap kewarganegaraan ekologis dan tanggung jawab warga negara melalui program ecovillage

\section{3-178. https://doi.org/10.1080/09644010500054848}

Seyfang, G. (2006). Ecological citizenship and sustainable consumption: Examining local organic food networks. Journal of Rural Studies, 22(4), 383-395. https://doi.org/10.1016/j.jrurstud.2006.01.003

Sriyanto. (2007). Kondisi lingkungan hidup di Jawa Tengah dan prospek pembangunan ke depan. Jurnal Geografi, 4(2), 107-113. https://doi.org/10.15294/jg.v4i2.102

Sunaedi, N., \& As'ari, R. (2018). Program ecovillage sebagai upaya perubahan perilaku masyarakat dalam pelestarian kawasan DAS Citanduy di Kecamatan Panumbangan Kabupaten Ciamis. Prosiding Seminar Nasional Geografi UMS IX 2018, 419-427.

Surakusumah, W. (2012). Konsensus global sebagai solusi permasalahan lingkungan global (pemanasan global).

Sya'ar, M. R. (2017). Uupaya Greenpeace dalam mengatasi limbah beracun di Tiongkok. JOM FISIP, 4(2), 111.

Wafiroh, S. F. (2018). Pengembangan masyarakat melalui program ecovillage dalam pelestarian lingkungan hidup: Studi Deskriptif di Desa Langensari Kecamatan Solokanjeruk Kabupaten Bandung. UIN Sunan Gunung Djati Bandung.

Wangsaatmaja, S., Sabar, A., \& Prasetiati, M. A. N. (2006). Permasalahan dan strategi pembangunan lingkungan berkelanjutan. Studi kasus: Cekungan Bandung. Indonesian Journal on Geoscience, 1(3), 163-171. https://doi.org/10.17014/ijog.vol1no3.20065

Wilcox, K. C. (2011). The importance of civic responsibility in higher performing middle schools: An empirical study. Education and Urban Society, 43(1), 26-41. https://doi.org/10.1177/0013124510379826 